\title{
PENGGUNAAN TEPUNG SAGU DALAM PEMBUATAN RENDANG TELUR DAN PENGARUHNYA TERHADAP KUALITAS KIMIA
}

\author{
SUKATNO, I. MIRDHAYATI dan D. FEBRINA \\ Fakultas Pertanian dan Peternakan Universitas Islam Negeri Sultan Syarif Kasim Riau \\ Kampus II Raja Ali Haji Jln. Soebrantas KM 16 Panam-Pekanbaru \\ E-mail: mirdhayati@gmail.com
}

\begin{abstract}
Rendang telur is one of the Indonesian local foods that were popular in west Sumatra community. Rendang telur is presented in combination egg crackers and dried rendang seasoning. Generally, the main ingredient used in making egg crackers was combination of rice flour and wheat flour. This research was conducted to study the using of sago flour as a main ingredient due to sago had high availability in Riau province and utilization of non rice starch. The aims of this research was to know the chemical properties of Rendang telur that were made by using sago flour. The experimental design was Complete Randomize Design with four treatments and four replications. The treatments were amount of sago flour that were used, consists of $A$ (rice flour $25 \mathrm{~g}$ as a control), B (sago flour $25 \mathrm{~g}$ ), C (sago flour $30 \mathrm{~g}$ ) and D (sago flour $35 \mathrm{~g}$ ). Variable analyzed were protein content, moisture content, lipid content, acid value and content of free fatty acid. The result show that the protein content ranged between 9.14-6.42\% wb, the moisture content ranged between 2.94-2.04\%, fat content ranged between 41.01-30.6\% wb, acid value and free fatty acid ranged between 1.70-2.14 $\mathrm{mg}$ and 1.09-1.37\%, respectively. It can be concluded that sago flour could use as replacer rice flour if amount added is not more than $30 \mathrm{~g}$ based on protein content. An addition of $35 \mathrm{~g}$ sago flour could reduce protein content, but non significance effect to moisture content, fat content, acid value and free fatty acid content.
\end{abstract}

Key words : Rendang telur, sago flour, chemical properties.

\section{PENDAHULUAN}

Rendang telur merupakan salah satu bentuk diversifikasi olahan pangan asal telur. Lazimnya rendang telur dibuat dari telur itik dan telur ayam ras. Bahan penyusun utama rendang telur terdiri atas telur, tepung, bumbu dan rempah-rempah. Rendang telur dibuat dalam bentuk keripik telur yang dicampur dengan bumbu rendang kering.

Telur merupakan salah satu produk ternak unggas yang mudah dicerna dan memiliki kandungan gizi lengkap, harganya relatif terjangkau oleh semua kalangan masyarakat dan mudah didapat. Kandungan gizi sebutir telur ayam dengan berat $50 \mathrm{~g}$ terdiri dari $6,3 \mathrm{~g}$ protein; 0,6 g karbohidrat; $5 \mathrm{~g}$ lemak, serta mengandung vitamin dan mineral yang lengkap (Sudaryani, 2003).

Rempah-rempah yang digunakan dalam pembuatan rendang mengandung berbagai senyawa bioaktif yang bersifat sebagai anti bakteri dan anti kapang. Hal ini membuat rendang memiliki daya simpan yang baik, yaitu sekitar tiga hari pada suhu kamar $\left(25-30^{\circ} \mathrm{C}\right)$ tanpa pemanasan ulang dan sembilan hari pada lemari pendingin (refrigerator) (Astawan, 1999). Penggunaan bumbu dan rempah juga berfungsi untuk meningkatkan cita rasa (Nurwanto, 2012).

Salah satu bahan penyusun penting dalam pembuatan rendang telur adalah tepung, karena berfungsi sebagai bahan pengikat dalam pembuatan keripik telur. Jenis tepung yang lazim digunakan dalam pembuatannya oleh masyarakat yaitu tepung terigu dan tepung beras. Penelitian sejenis telah dilakukan oleh Nugra (2011), tentang pembuatan rendang telur itik menggunakan bahan pengikat tepung beras. Hasil penelitian tersebut menunjukkan penambahan telur itik pada level $100 \mathrm{~g}$ sampai $175 \mathrm{~g}$ tidak mempengaruhi nilai protein dan organoleptik. Kadar protein 
berkisar 2,9\%-4,3\% dan untuk nilai organoleptik tekstur 3,73-3,91 (agak renyah hingga renyah), rasa 3,48-3,78 (agak gurih hingga gurih), bau 3,76-3,88 (agak harum hingga harum) dan warna 3,66-3,83 (agak kuning kecokelatan hingga kuning kecoklatan).

Tepung sagu dilaporkan dapat digunakan sebagai bahan pengikat dalam pembuatan kerupuk ikan gabus (Laiya dkk, 2014). Kemampuan mengikat tepung sagu berasal dari kandungan pati yang tinggi, kandungan pati sagu mengandung komponen bahan kering amilosa 27\%; amilopektin $73 \%$; protein $0,1 \%$; lemak $0,1 \%$; abu 0,2 \%; fosfor 0,02\% (Swinkels 1985 dalam Singhal et al, 2008).

Tepung sagu dapat dimanfaatkan sebagai diversifikasi pangan sumber karbohidrat, secara nasional sagu paling rendah pemanfaatannya dibandingkan komoditas pangan non beras lainnya seperti singkong, ubi jalar, kentang dan jagung. Kadar karbohidrat sagu setara dengan karbohidrat yang terdapat pada tepung beras, singkong dan kentang, bahkan dibandingkan dengan tepung jagung dan terigu kandungan karbohidrat tepung sagu relatif lebih tinggi (Fadila, 2011). Penelitian ini, menggunakan tepung sagu sebagai pengganti tepung beras pada pembuatan rendang telur. Hal ini berdasarkan ketersediaan tepung sagu yang cukup banyak di Riau. Penelitian ini dilakukan dengan tujuan untuk mengetahui kualitas kimia rendang telur ayam ras yang dibuat dari tepung sagu ditinjau dari kadar protein, kadar air, kadar lemak, bilangan asam dan asam lemak bebasnya.

\section{MATERI DAN METODE}

Penelitian dilaksanakan bulan Maret sampai bulan Mei 2016, di Laboratorium Teknologi Pascapanen Fakultas Pertanian dan Peternakan Universitas Islam Negeri Sultan Syarif Kasim Riau.

\section{Bahan dan Alat}

Bahan utama yang digunakan dalam penelitian adalah telur ayam ras, tepung beras, tepung sagu, bumbu rendang dan bahan tambahan yang digunakan dalam pembuatan rendang telur. Bahan lainnya adalah bahan kimia yang digunakan dalam analisis kadar protein, kadar lemak dan bilangan asam lemak bebas.

Alat-alat yang digunakan dalam penelitian adalah wajan teflon, gelas ukur, kompor gas, blender, labu Kjeldahl, erlenmeyer, buret, timbangan analitik, tang, penjepit, sendok dan alat tulis.

\section{Metode Penelitian}

Penelitian dirancang secara eksperimen menggunakan Rancangan Acak Lengkap (RAL) terdiri dari 4 perlakuan masingmasing dengan 4 ulangan. Perlakuan adalah formulasi rendang telur yang terdiri atas 3 formulasi dengan tepung sagu, dan 1 formulasi dengan tepung beras sebagai kontrol. Formulasi dan prosedur pembuatan rendang telur berdasarkan penelitian Nugra (2011) yang sudah dimodifikasi sesuai kebutuhan penelitian ini. Formulasi keripik rendang telur dan bumbu yang digunakan ditunjukkan pada Tabel 1. Peubah yang diamati meliputi kandungan protein, kadar air, kadar lemak, bilangan asam dan asam lemak bebas.

\section{Prosedur Penelitian}

Penelitian terdiri atas tahapan persiapan, dan tahapan pembuatan rendang telur. Pembuatan keripik telur yaitu dengan menambahkan tepung sagu menurut perlakuan, bawang putih, bawang merah, jahe, garam serta kapur sirih ke dalam larutan telur, kemudian diaduk hingga merata. Tahap selanjutnya adalah pre-cooking dengan cara pencetakan kerupuk berbentuk lembaran-lembaran pada wajan Teflon, lembaran-lembaran tersebut 
dipotong berbentuk jajaran genjang dengan ukuran $\pm 4-5 \mathrm{~cm}$, selanjutnya lembaran tersebut digoreng di dalam wajan dengan suhu $140^{\circ} \mathrm{C}-210^{\circ} \mathrm{C}$.

Tabel 1. Formulasi bahan penelitian

\begin{tabular}{|c|c|c|c|c|}
\hline \multirow{2}{*}{$\begin{array}{c}\text { Bahan } \\
\text { (g) }\end{array}$} & \multicolumn{3}{|c|}{ Formulasi } & \multirow[b]{2}{*}{$\mathrm{D}$} \\
\hline & A & B & $\mathrm{C}$ & \\
\hline \multicolumn{5}{|l|}{ a. Keripik Rendang Telur } \\
\hline Telur ayam ras & 100,0 & 100,0 & 100,0 & 100,0 \\
\hline Tepung sagu & - & 25,0 & 30,0 & 35,0 \\
\hline Tepung beras & 25,0 & - & - & - \\
\hline Bawang putih & 15,0 & 15,0 & 15,0 & 15,0 \\
\hline Bawang merah & 10,0 & 10,0 & 10,0 & 10,0 \\
\hline Jahe & 5,0 & 5,0 & 5,0 & 5,0 \\
\hline Garam & 2,5 & 2,5 & 2,5 & 2,5 \\
\hline Kapur & 0,2 & 0,2 & 0,2 & 0,2 \\
\hline \multicolumn{5}{|l|}{ b. Bumbu Kering } \\
\hline Lengkuas & 22,5 & 22,5 & 22,5 & 22,5 \\
\hline Kunyit & 5,0 & 5,0 & 5,0 & 5,0 \\
\hline Jahe & 17,5 & 17,5 & 17,5 & 17,5 \\
\hline Serai & 2,5 & 2,5 & 2,5 & 2,5 \\
\hline Bawang putih & 20,0 & 20,0 & 20,0 & 20,0 \\
\hline Bawang merah & 20,0 & 20,0 & 20,0 & 20,0 \\
\hline Ketumbar & 5,0 & 5,0 & 5,0 & 5,0 \\
\hline Cabai merah & 25,0 & 25,0 & 25,0 & 25,0 \\
\hline Bumbu rending & 2,5 & 2,5 & 2,5 & 2,5 \\
\hline Garam & 10,0 & 10,0 & 10,0 & 10,0 \\
\hline Santan kelapa (buah) & $1 / 2$ & $1 / 2$ & $1 / 2$ & $1 / 2$ \\
\hline
\end{tabular}

Pembuatan bumbu kering yaitu memasak semua bahan-bahan seperti lengkuas, kunyit, jahe, serai, bawang putih, bawang merah, ketumbar, cabai merah, bumbu kari, garam dan santan kelapa ke dalam wajan dan diaduk hingga merata. Proses pemasakan ini membutuhkan waktu \pm 5 jam. Tahapan akhir adalah mencampur bumbu rendang kering dengan keripik telur.

\section{Prosedur Analisis}

Kandungan protein dan kadar lemak dianalisis menurut metode Foss Analytical, 2003a; 2003b. Kadar air menurut AOAC 1993 dan analisis bilangan asam dan asam lemak bebas berdasarkan AOAC, Official method 940.28.

\section{Analisis Data}

Data penelitian yang dihasilkan diolah secara statistik menggunakan analisis ragam menurut Rancangan Acak Lengkap (RAL). Jika perlakuan berpengaruh nyata pada a 0,05, dilakukan uji lanjut Beda Nyata Terkecil (BNT). 


\section{HASIL DAN PEMBAHASAN}

\section{Kandungan Protein}

Nilai rata-rata kadar protein rendang telur dari formulasi berbeda ditunjukkan pada Tabel 1. Uji analisis sidik ragam menunjukkan perlakuan penggunaan tepung sagu mempengaruhi kadar protein rendang telur.

Tabel 1. Kadar protein rendang telur dari formulasi yang berbeda

\begin{tabular}{ccc}
\hline $\begin{array}{c}\text { Perbandingan } \\
\text { tepung beras : tepung sagu }(\mathrm{g})\end{array}$ & $\begin{array}{c}\text { Kadar protein } \\
(\% \mathrm{bb})\end{array}$ & $\begin{array}{c}\text { Kadar protein } \\
(\% \mathrm{bk})\end{array}$ \\
\hline A $(25: 0)$ & $8,70^{\mathrm{b}} \pm 1,43$ & $8,999^{\mathrm{b}} \pm 1,47$ \\
B $(0: 25)$ & $9,14^{\mathrm{b}} \pm 1,74$ & $9,42^{\mathrm{b}} \pm 1,88$ \\
C $(0: 30)$ & $7,91^{\mathrm{ab}} \pm 1,03$ & $8,08^{\mathrm{ab}} \pm 1,03$ \\
D $(0: 35)$ & $6,42^{\mathrm{a}} \pm 0,75$ & $6,62^{\mathrm{a}} \pm 0,79$ \\
\hline
\end{tabular}

Ket: Data disajikan dalam nilai rata-rata dan standard deviasi.

Superskrip berbeda pada kolom yang sama menunjukkan berbeda nyata $(\mathrm{P}<0,05)$, berat basah (bb) dan berat kering (bk).

Berdasarkan Tabel 1. dapat dilihat penggunaan tepung sagu sampai $30 \mathrm{~g}$ memiliki kandungan protein rendang telur yang sama dengan rendang telur dengan bahan pengikat tepung beras. Penggunaan tepung sagu sampai 35 g nyata menurunkan kadar protein rendang telur. Hal ini diduga karena kandungan protein rendang telur dipengaruhi oleh penambahan tepung sagu, dengan bertambahnya tepung sagu yang digunakan, akan menurunkan kadar protein menjadi 6,42\% berat basah. Menurut Kam (1992) kadar protein pada tepung sagu kurang lebih $0,70 \%$ dan pada tepung beras kurang lebih 6,80\%. Namun demikian, kandungan protein rendang telur penelitian ini lebih tinggi bila dibandingkan hasil penelitian Nugra (2011), kadar protein rendang telur itik berkisar 2,9-4,7\% bb.

\section{Kadar Air}

Nilai rata-rata kadar air rendang telur dari formulasi berbeda ditunjukkan pada Tabel 2. Uji analisis sidik ragam menunjukkan perlakuan penggunaan tepung sagu tidak mempengaruhi kadar air rendang telur. Hal ini berkaitan dengan kadar air tepung beras dan tepung sagu yang rendah yakni 12,1\% dan 15,5\%.

Kadar air rendang telur yang rendah disebabkan oleh pengaruh proses pemasakan dengan cara penggorengan. Suhu penggorengan yang digunakan berkisar $140^{\circ} \mathrm{C}-210^{\circ} \mathrm{C}$ sehingga air yang ada dalam kerupuk rendang telur menguap menghasilkan tekstur yang renyah dan meningkatkan bahan kering rendang telur. Bila ditinjau dari fisiknya, rendang telur termasuk kategori kerupuk yang diberi bumbu.

Menurut Badan Standar Nasional Indonesia (1996) standar olahan kerupuk beras yaitu SNI 01-4307-1996 kadar air maksimal pada kerupuk adalah 12\% mentah dan $8 \%$ sudah digoreng. Kadar air kerupuk rendang telur pada penelitian ini memenuhi kriteria yang ditetapkan SNI 01-4307-1996. Pada penelitian ini nilai kadar air lebih rendah bila dibandingkan hasil penelitian yang dilaporkan oleh Lestari (2015), yaitu nilai kadar air sebesar 3,61\% berat basah pada kerupuk melinjo. 
Tabel 2. Kadar air rendang telur dari formulasi yang berbeda

\begin{tabular}{ccc}
\hline $\begin{array}{c}\text { Perbandingan } \\
\text { tepung beras : tepung sagu }(\mathrm{g})\end{array}$ & $\begin{array}{c}\text { Kadar air } \\
(\%)\end{array}$ & $\begin{array}{c}\text { Bahan kering } \\
(\%)\end{array}$ \\
\hline A $(25: 0)$ & $3,18 \pm 0,28$ & $96,82 \pm 0,28$ \\
B $(0: 25)$ & $2,94 \pm 1,29$ & $97,06 \pm 1,29$ \\
C $(0: 30)$ & $2,19 \pm 0,51$ & $97,81 \pm 0,51$ \\
D $(0: 35)$ & $2,04 \pm 0,88$ & $97,96 \pm 0,88$ \\
\hline
\end{tabular}

Ket : Data disajikan dalam nilai rata-rata dan standard deviasi

\section{Kandungan Lemak}

Nilai rata-rata kadar lemak rendang telur dari formulasi berbeda ditunjukkan pada Tabel 3. Uji analisis sidik ragam menunjukkan perlakuan penggunaan tepung sagu tidak mempengaruhi kadar lemak rendang telur.

Tabel 3. Kandungan lemak rendang telur dari formulasi yang berbeda

\begin{tabular}{ccc}
\hline $\begin{array}{c}\text { Perbandingan } \\
\text { tepung beras : tepung sagu }(\mathrm{g})\end{array}$ & $\begin{array}{c}\text { Kadar lemak } \\
(\% \mathrm{bb})\end{array}$ & $\begin{array}{c}\text { Kadar lemak } \\
(\% \mathrm{bk})\end{array}$ \\
\hline A $(25: 0)$ & $36,99 \pm 5,66$ & $38,20 \pm 5,80$ \\
B $(0: 25)$ & $38,17 \pm 6,51$ & $39,38 \pm 7,06$ \\
C $(0: 30)$ & $30,67 \pm 6,68$ & $31,25 \pm 6,76$ \\
D $(0: 35)$ & $41,01 \pm 5,76$ & $41,70 \pm 5,56$ \\
\hline
\end{tabular}

Ket : Data disajikan dalam nilai rata-rata dan standard deviasi, berat basah (bb) dan berat kering (bk).

Pada penelitian ini, kadar lemak rendang telur lebih ditentukan oleh lemak yang terkandung dalam bahan baku kerupuk rendang telur dan bumbu rendang kering yang digunakan. Faktor yang mempengaruhi kadar lemak pada rendang telur adalah formulasi bahan yang digunakan, waktu kontak dengan minyak goreng dan campuran bumbu-bumbu yang ada pada rendang telur tersebut serta jumlah minyak yang ditahan oleh kerupuk sebagai akibat proses penggorengan. Hal ini sesuai pendapat Septiva (2013) pada proses penggorengan, akan terjadi penyerapan minyak pada kerupuk, sehingga proses penggorengan juga mempengaruhi kadar lemak.
Kandungan lemak rendang telur pada penelitian ini cenderung sama dengan penelitian Wahyuningtyas dkk. (2014) yang meneliti formulasi kerupuk tepung pisang yang menggunakan bahan pengikat tepung tapioka dan terigu. Hasil penelitiannya menunjukkan kadar lemak kerupuk tepung pisang berkisar 19,26-41,85\% berat basah.

\section{Bilangan Asam dan Asam Lemak Bebas}

Nilai rata-rata bilangan asam dan asam lemak bebas rendang telur dari formulasi berbeda ditunjukkan pada Tabel 4. Uji analisis sidik ragam menunjukkan perlakuan penggunaan tepung sagu tidak mempengaruhi bilangan asam dan asam lemak bebas rendang telur. 
Tabel 4. Kadar bilangan asam dan asam lemak bebas rendang telur dari formulasi yang berbeda

\begin{tabular}{ccc}
\hline $\begin{array}{c}\text { Perbandingan } \\
\text { tepung beras : tepung sagu }(\mathrm{g})\end{array}$ & $\begin{array}{c}\text { Bilangan asam } \\
(\mathrm{mg})\end{array}$ & $\begin{array}{c}\text { Asam lemak bebas } \\
(\%)\end{array}$ \\
\hline A $(25: 0)$ & $2,12 \pm 0,44$ & $1,36 \pm 0,28$ \\
B $(0: 25)$ & $2,10 \pm 0,42$ & $1,35 \pm 0,27$ \\
C $(0: 30)$ & $2,14 \pm 0,31$ & $1,37 \pm 0,20$ \\
D $(0: 35)$ & $1,70 \pm 0,31$ & $1,09 \pm 0,20$ \\
\hline
\end{tabular}

Ket : Data disajikan dalam nilai rata-rata dan standard deviasi.

Berdasarkan Tabel 4. bilangan asam dan asam lemak bebas pada setiap perlakuan menunjukkan sudah terjadi kerusakan lemak pada saat proses pemasakan. Bilangan asam lemak bebas maksimal pada minyak goreng adalah 0,30\% (SNI 01-37412002). Bilangan asam dan asam lemak bebas memiliki korelasi yang positif, apabila nilai bilangan asam tinggi maka nilai asam lemak bebas juga tinggi. Hasil hidrolisis lemak dalam bahan pangan tidak hanya mengakibatkan bau yang tidak enak, tetapi juga dapat menurunkan nilai gizi, karena kerusakan vitamin dan asam lemak esensial dalam lemak (Ketaren, 1989). Semakin tingginya kadar asam lemak bebas pada setiap penyimpanan menandakan rendang telah mengalami tanda-tanda kerusakan lemak (Rahmadana, 2013).

Nilai bilangan asam dan asam lemak bebas pada penelitian ini lebih rendah dibandingkan hasil penelitian yang dilaporkan Rahmadana (2013), yang meneliti masa simpan rendang ikan tuna dalam kemasan vakum selama penyimpanan pada suhu ruang dan dingin. Hasil penelitian tersebut menunjukkan kadar asam lemak bebas berkisar 1,13\%$3,93 \%$. Bilangan asam adalah ukuran dari jumlah asam lemak bebas, kandungan asam lemak bebas pada makanan yang bermutu baik adalah yang terdapat sedikit sekali jumlah asam lemak bebasnya. Apabila bilangan asam dan asam lemak bebas pada suatu produk makanan itu tinggi, maka telah menunjukan awal terjadinya kerusakan pada lemak, dan merupakan tanda adanya proses ketengikan dalam bahan pangan (Rahmadana, 2013).

\section{KESIMPULAN DAN SARAN}

\section{Kesimpulan}

Tepung sagu dapat digunakan sebagai bahan pengikat rendang telur. Penambahan tepung sagu sampai konsentrasi $30 \mathrm{~g}$ dapat menggantikan tepung beras sebagai bahan pengikat pada pembuatan rendang telur dilihat dari kualitas kimianya (kadar air, kadar protein, kadar lemak, bilangan asam dan kadar asam lemak bebas).

\section{Saran}

1. Perlu dilakukan penelitian lebih lanjut untuk mengetahui daya simpan rendang telur menggunakan tepung sagu yang disimpan pada suhu kamar.

2. Perlu dilakukan penelitian lebih lanjut untuk mengetahui mutu organoleptik dan mutu fisik rendang telur menggunakan tepung sagu.

\section{DAFTAR PUSTAKA}

Astawan, M. 1999. Rendang dan Kalio. Departeman Teknologi Pangan dan Gizi. Institut Pertanian Bogor. Bogor.

Badan Standar Nasional Indonesia. 1996 Standar Nasional Indonesia: 4307. Standar Olahan Kerupuk Beras. Dewan Standar Nasional. Jakarta. 
Fadila, I. 2011. Potensi Sagu dalam Upaya Diversifikasi Pangan. Universitas Terbuka. Tangerang Selatan.

Kam, N. O. 1992. Daftar Analisis Bahan Makanan. Fakultas Kedokteran Universitas Indonesia. Jakarta, 53p.

Kataren, S. 1986. Pengantar Teknologi Minyak dan Lemak Pangan. UI Press, Jakarta.

Laiya, N., R. M. Harmain., N. Yusuf. 2014. Formulasi Kerupuk Ikan Gabus (Chana striata) yang Disubstitusi dengan Tepung Sagu. Artikel Ilmiah. Fakultas Ilmu Pertanian Universitas Negri Gorontalo. Gorontalo.

Lestari, S. M. 2015. Karakterisasi Fisikokimia Kerupuk Melinjo sebagai Upaya Diversifikasi Produk Olahan Melinjo. Pros Sem Nas Masy Biodiv Indon. 1(1):131-135.

Nugra, A E. 2011. Kadar Protein dan Mutu Organoleptik Rendang Telur Itik dengan Level Telur Itik yang Berbeda. Skripsi. Fakultas Pertanian dan Peternakan Universitas Islam Negri Sultan Syarif Kasim Riau. Pekanbaru.

Nurwanto. 2012. Sifat Organoleptik Rendang Kelinci dan Rendang Sapi. Skripsi. Fakultas Pertanian dan Peternakan Universitas Islam Negri Sultan Syarif Kasim Riau. Pekanbaru.
Rahmadana. 2013. Analisa Masa Simpan Rendang Ikan Tuna dalam Kemasan Vakum Selama Penyimpanan pada Suhu Ruang dan Dingin. Skripsi. Fakultas Pertanian Universitas Hasanuddin. Makassar.

Septiva, D. R. 2013. Pengaruh Jumlah Daging Belut (Monopterus albus) dan Penambahan Puree Wortel (Daucus carota) pada Hasil Jadi Kerupuk. e-journal Boga, 2(3):95-103.

Singhal, R. S., J. F. Kennedy., S. M. Gopalakrishnan., A. Kaczmareck., C. J. Knill. P. F. Akmar. 2008. Industrial Production, Processing, and Utilization of Sago PalmDerived Products. Charbohydrate Polimers, 72:1-20.

Sudaryani. 2003. Kandungan gizi telur. Universitas Sumatra Utara. Medan.

Wahyuningtyas, N., Basito., dan W. Atmaka. 2014. Kajian Karakteristik Fisikokimia dan Sensoris Kerupuk Berbahan Baku Tepung Terigu, Tepung Tapioka dan Tepung Pisang Kepok Kuning. Jurnal Teknosains Pangan, 3(2):76-85. 